\title{
A Study of the Impact of the Fiscal Decentralization on the Regional Disparity: Focus on 16 Metropolitan and Provincial Governments of South Korea
}

\author{
Dongjin Moon \\ Institute of Governmental Studies, Department of Public Administration, Korea University \\ kayil9967@gmail.com
}

\begin{abstract}
This paper examined the impact of fiscal decentralization of regional disparity by analyzing a 16 Metropolitan and Provincial Governments of South Korea using the multiple regression analysis. According to the analysis, local governments' revenue and expenditure decentralization have a different impact on regional disparity each other. Financial independence ratio and fiscal self-reliance ratio indicators, those relate to local governments' revenue decentralization have a statistically significant correlation with regional disparity. However, the impact of local governments' expenditure decentralization on regional disparity was relatively weak. There is a limit to conclude that the progress of decentralization has a positive influence on easing the regional disparities. For these reasons, in order to achieve balanced regional development and easing the regional disparity, it is necessary not only to improve the financial capacity of each local government and progress fiscal decentralization, but also consider the policy that includes central governments' fiscal adjustment intervention to be parallel.
\end{abstract}

Keywords: Fiscal decentralization, Regional disparity, Multiple regression analysis

\section{Introduction}

In South Korea, the fiscal decentralization policy has been taken as the key of local decentralization since the local government system was restored in the 1990s. Naturally, fiscal decentralization has become one of the most important issues of local government policy.

From a theoretical point of view, there are diverse reasons why the fiscal decentralization can reduce regional disparity. They argued that fiscal decentralization implies better informed and more specific public local policies. Because fiscal decentralization can arouse a more efficient supply of public services and goods for residents and forward a better match between local government's policies and citizen needs. In addition, lower level local governments can have more information about what citizens need and, furthermore, can more adjust their local policies to local preferences.

On the other hands, some researchers mentioned that fiscal decentralization has possibility to widen regional disparities. They explained that fiscal decentralization reduces the redistributive local governments' capacity or the central governments' intervention. Under the circumstances, relatively wealthier regions will grow faster than poorer regions.

The previous studies also have been suggested the relationships between decentralization and regional development by empirical research based on various case studies and cross-country comparative studies. The conclusion of previous studies supports an opposite 
relationship between fiscal decentralization and regional disparities.

This paper examined the impact of fiscal decentralization of regional disparity by analyzing a 16 Metropolitan and Provincial Governments of South Korea. Based on the result of analysis, this paper analyzed the impact of fiscal decentralization using the multiple regression analysis.

\section{Empirical studies about the impact of local fiscal decentralization on regional disparity}

From a theoretical perspective, local fiscal capacity and its decentralization can influence on regional convergence. They argued that local fiscal decentralization can reduce regional disparity by attributing economic activity, cost of service, and political considerations of equalization and national unity.

Fiscal decentralization has the latent ability to promote the competition among local governments, and this can minimize local governments' inefficient act and, consequently, can promote regional convergence (Brennan and Buchanan 1980; Weingast 1995; McKinnon 1997; Qian and Weingast 1997). Moreover, citizens can use the performance of higher-performing authority as a benchmark and this will increase the efficiency in public goods that producted by local governments. (Salmon 1987; Breton 1996).

Zhiriong Jerry Zhao (2008) traced the evolution of intergovernmental relations in China since 1978. He analyzed fiscal disparity through the methods of inequality decomposition, such as the Gini index and its standard decomposition. According to his analysis, China's provinciallevel fiscal disparities have decreased during 1984-1993. However, the fiscal disparity of China remained high during the post-1994, because equalization effects of central transfers have diminished. According to regression-based inequality decomposition, the dispersion of fiscal measures may be attributed to economic activity, cost of service, and political considerations of equalization and national unity (Zhiriong Jerry Zhao, 2008).

Zhirong Jerry Zhao \& Yilin Hou (2008) examined the local option sales taxes (LOST) on fiscal disparities among local governments using the data of the 159 Georgia counties during 1970-2000. They provided further insight of LOST as new sources of public revenue and helped the policy decision maker of state to determine what would diminish local fiscal disparities. This study demonstrated that adding sales tax exportation would increase the dispersion associated with the income-based revenue. In other words, the LOST does exacerbate public income disparity (Zhirong Jerry Zhao \& Yilin Hou, 2008).

Yilmaz, et al. (2006) measures the fiscal disparities across the 50 states in fiscal year 2002 through analyzing each state's public tax income capacity, expenditure, and overall level of fiscal capacity. Tax income and expenditure are assigned to different levels of governments across different states. Also, they combine information about revenues capacity and expenditure needs for the local government. They used a methodology based on economic and demographic conditions found in the states. A state's expenditure need gauges the extent to which its state and local governments face conditions that raise or lower the cost and need for public services. Fiscal ability assesses each state's ability to raise revenues relative to its expenditure needs (Yesim Yilmaz,et al., 2006).

Bartels, L. M., et al. (2005) examined the differential responsiveness of U.S. senators 
to the preferences of affluent, middle-class, and poor constituents. He used broad summary measures of senators' voting behavior, as well as specific votes on the minimum wage, resident's rights, government expenditure, and abortion. According to his analysis, incomebased disparities appeared to be unrelated to disparities in turnout and political knowledge and only weakly related to disparities in the extent of constituents' contact with senators and their staffs (Bartels, L. M., 2005).

Shahateet (2006) measured and explained the extent of regional economic inequalities in Jordan. He used the raw data of two national household surveys on expenditure and income that covers 5,971 and 11,153 households in 1997 and 2002. He applied four measures of inequality: the Gini index, Atkinson's index, the 90/10 ratios, and the standard deviation of the natural logarithm. He concluded that the economic disparity increased over the five years period following 1997. The overall increase can be estimated at about 17\%, indicating a shift in the function of income distribution so that income disparity may increase. In this sense, he argued that regional economic inequality in Jordan is serious and there is a need for a more space-balanced approach (Mohammed Issa Shahateet, 2006).

According to Boadway, et al. (2004), they emphasized that revenue equalization reflects the current equalization system. According to their study, Section 36 of the Constitution Act. 2 requires different needs for public services that they incorporated in the equalization system. The federal-provincial system assumes that such needs are similar to per capita in state areas. They suggested two dimensions that explain adequacy of equalization and its fairness of equalizations. In that statement, they analyzed what would be required for tax income equalization. Also, they tried to find the deviations of the current system from the ideal (Boadway, R., et al., 2004).

Martinez-Vazquez and Rider (2006) argued that the political systems of China and India have similarities in the approaches to decentralization. China and India have similar issues, such as high transfer dependency and low tax income autonomy. Naturally, they have a lack of fiscal discipline among local governments. Also, the quality of service that served by local government is poor. According to their study, poor quality of service and the lack of fiscal discipline have a bad influence on sustaining economic growth. In their study, China and India have little accountability at the local level and local officials did not control their budget effectively. Because expenditure responsibilities and tax income task of local government of both country belong to the states. They concluded both countries have to develop comprehensive strategies that link intergovernmental fiscal systems (Martinez-Vazquez and Rider, 2006).

Despite the potentially crucial impact of institutional quality on the relationship between fiscal decentralization and regional disparities however, this impact has not been explored directly in empirical work. 


\section{Research Design}

1) Research Question and Hypothesis

This study is research about the impact of fiscal decentralization on the regional disparity. The research question of this study is that "does fiscal decentralization influence in the change of regional disparity?" To verify this research question, this paper examines the relationship between local fiscal decentralization and regional disparity.

\section{2) Unit of Analysis}

To measure fiscal decentralization and regional disparity, this paper selected 16 Metropolitan and Provincial Government of South Korea and collected their data from 2000 to 2015.

[Table 1] List of Metropolitan and Provincial Areas of Korea

\begin{tabular}{c|c|c}
\hline Number & Name & Unit \\
\hline \hline 1 & Seoul & Metropolitan Area \\
\hline 2 & Busan & Metropolitan Area \\
\hline 3 & Incheon & Metropolitan Area \\
\hline 4 & Daejeon & Metropolitan Area \\
\hline 5 & Gwangju & Metropolitan Area \\
\hline 6 & Daegu & Metropolitan Area \\
\hline 7 & Ulsan & Metropolitan Area \\
\hline 8 & Gyeonggi-do & Provincial Area \\
\hline 9 & Gangwon-do & Provincial Area \\
\hline 10 & Chungcheongbuk-do & Provincial Area \\
\hline 11 & Chungcheongnam-do & Provincial Area \\
\hline 12 & Jeollabuk-do & Provincial Area \\
\hline 13 & Jeollanam-do & Provincial Area \\
\hline 14 & Gyeongsangbuk-do & Provincial Area \\
\hline 15 & Gyeongsangnam-do & Provincial Area \\
\hline 16 & Jeju-do & Provincial Area \\
\hline
\end{tabular}

4) Empirical Methodology

(1) Measuring Regional disparity and fiscal decentralization

To measure disparity of level of fiscal decentralization of each metropolitan areas and regional disparity, we need to calculate disparity index that shows single level of disparity. So this study uses a coefficient of variation. Coefficient of variation is method to measure relative dispersion. In other word, a coefficient of variation is a value of standard deviation that is divided by arithmetic mean. 
Standard deviation shows how much variation or dispersion from the average. So standard deviation is the one of good device to measure disparity. However, if dispersion of a group is an average change, standard deviation will change. Naturally, standard deviation is not a good measure for change of local disparity. For those reasons, we need to measure value that is not influenced by the change of average and use coefficient of variation. To measure the coefficient of variation, the mathematical formulation is as follows;

$$
V=\frac{\sqrt{\sum_{t=1}^{n}(y-\bar{y})^{2} / n}}{\bar{u}}
$$

In this formulation, y means local fiscal capacity, $\bar{y}$ means the average of local fiscal capacity extending local area $\mathrm{n}$. If $\mathrm{V}$ is large, disparity of a local area is large. [Table 2] is variables that used in this paper to examine the correlation between fiscal decentralization and regional disparity.

[Table 2] Variables for Analysis

\begin{tabular}{|c|c|c|}
\hline & Variable Name & Formula \\
\hline \multirow{7}{*}{$\begin{array}{l}\text { Regional Disparity } \\
\text { Indicators }\end{array}$} & GRDP per Capita & GRDP/Population \\
\hline & $\begin{array}{l}\text { Private consumption Expenditure } \\
\text { per capita }\end{array}$ & $\begin{array}{l}\text { Private consumption } \\
\text { Expenditure/Population }\end{array}$ \\
\hline & $\begin{array}{l}\text { Percentage of employees with } \\
\text { college graduated }\end{array}$ & $\begin{array}{l}\text { (Number of Empolyees with } \\
\text { College Graduated/Number of } \\
\text { Total Employees)*100 }\end{array}$ \\
\hline & $\begin{array}{l}\text { Percentage of research and } \\
\text { development costs per GRDP }\end{array}$ & $\begin{array}{l}\text { (Cost of Research and } \\
\text { Developent/GRDP)*100 }\end{array}$ \\
\hline & Industrial Property right granted & $\begin{array}{l}\text { (Number of Industrial Property } \\
\text { right granted/Population)* } 100\end{array}$ \\
\hline & $\begin{array}{l}\text { Percentage of population ages } 15- \\
64\end{array}$ & $\begin{array}{l}\text { (Number of } 15-64 \text { age } \\
\text { population/Total Population) } * 100\end{array}$ \\
\hline & Ageing Index & $\begin{array}{l}\text { (Number of population ages over } \\
65 \text { year old/Number of population } \\
\text { ages } 0-14 \text { year old)*100 }\end{array}$ \\
\hline
\end{tabular}




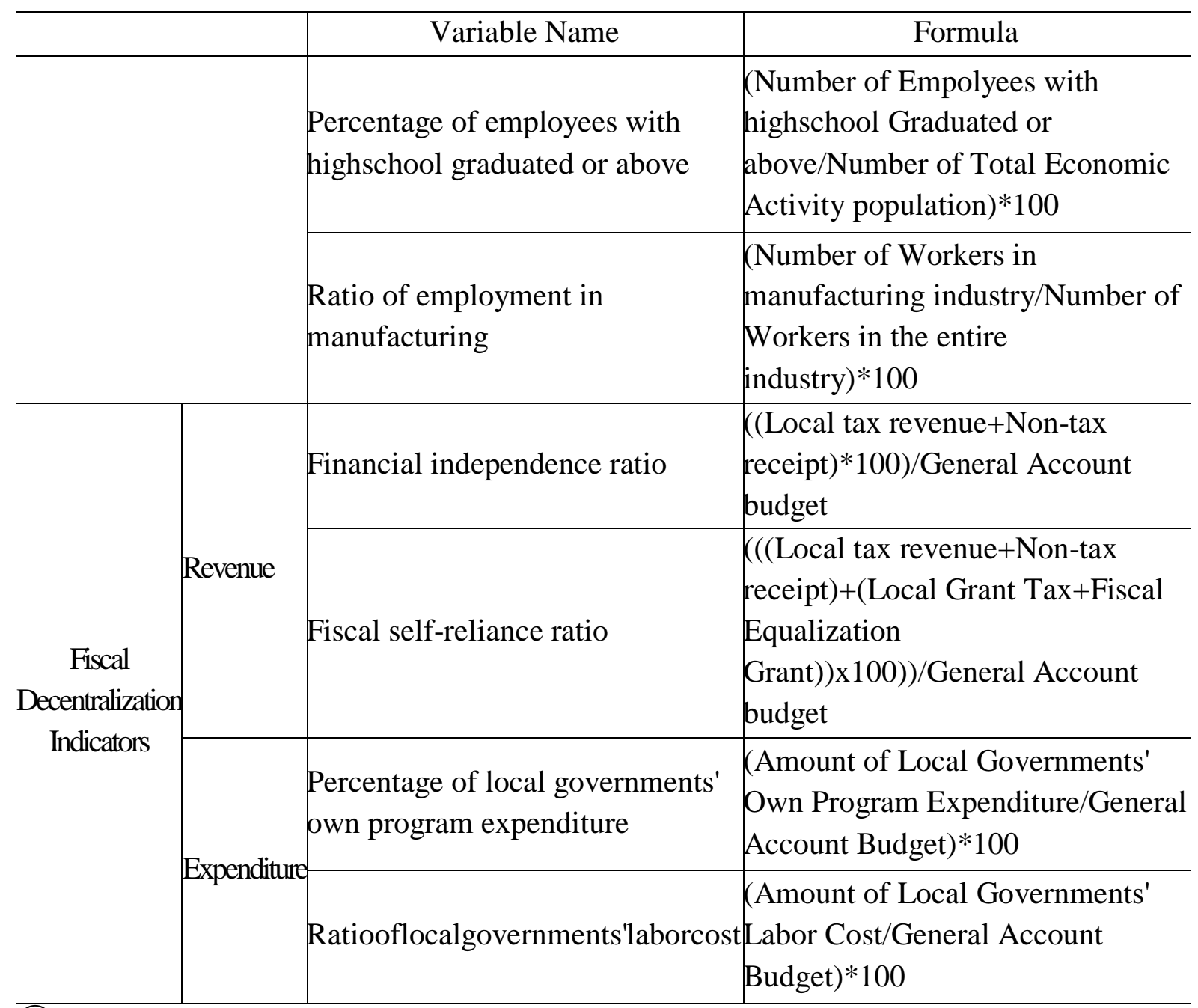

(2) Examine relationship between local fiscal decentralization and regional disparity

This study will use regression analysis to find the relationship between disparity of level of fiscal decentralization of each metropolitan areas and regional disparity. Regression analysis figures the causal relation between independent variable and dependent variable. If independent variables are multiple, such analysis is called the multiple regression analysis. The independent variance $x$ and the dependent variance $y$ is given by this formula;

$$
\mathrm{y}=\beta_{0}+\beta_{1} x
$$

According to this formula, $\beta_{0}$ means the intercept (or constant) and $\beta_{1}$ means the $x$ (independent variable) coefficient, $x$ represents the slope of the linear line of the equation.

\section{Results}

1) Trend of Regional Disparity

As a result of calculating the regional disparity of 16 metropolitan and Provincial 
Government of South Korea by coefficient of variance, regional disparity tends to decrease since 2000. However the disparity of the percentage of 15-64 year old population and the proportion of manufacturing employment, those show the existence of the potential workforce in the area cooperating with regional economic development have increased since 2000.

[Table 3] Trend of the Regional Disparity (2000-2015)

\begin{tabular}{|c|c|c|c|c|c|c|c|c|c|}
\hline \multirow{2}{*}{ Year } & \multirow{2}{*}{ GRDP } & \multirow{2}{*}{\multicolumn{2}{|c|}{$\begin{array}{l}\text { Consumption College } \\
\text { Expenditure Graduated }\end{array}$}} & \multirow{2}{*}{$\mathrm{R} \& \mathrm{D}$} & \multirow{2}{*}{ IP } & $15-64$ & \multicolumn{3}{|c|}{ Ageing HighschoolManufacturing } \\
\hline & & & & & & Population & Index & Graduated & Employment \\
\hline 2000 & 0.375 & 0.051 & 0.273 & 1.552 & 0.765 & 0.029 & 0.379 & 0.145 & 0.447 \\
\hline 2001 & 370 & 0.065 & 0.263 & 1.452 & 0.735 & 0.031 & 0.377 & 0.141 & 0.432 \\
\hline 2002 & .371 & 0.080 & 0.257 & 1.421 & 0.753 & 0.033 & 0.378 & 0.137 & 0.435 \\
\hline 2003 & 342 & 091 & 0.258 & 1.484 & 0.771 & 0.035 & 0.373 & 0.135 & 0.44 \\
\hline 2004 & 0.370 & 0.103 & 0.241 & 1.391 & 0.752 & 0.037 & 0.369 & 0.125 & 0.450 \\
\hline 2005 & 0.361 & 0.106 & 0.236 & 1.406 & 0.789 & 0.038 & 0.362 & 0.123 & 0.453 \\
\hline 2006 & 0.354 & 0.106 & 0.232 & 1.337 & 0.814 & 0.039 & 0.353 & 0.120 & 0.47 \\
\hline 2007 & 0.365 & 0.108 & 0.232 & 1.267 & 0.766 & 0.042 & 0.344 & 0.120 & 0.478 \\
\hline 2008 & 0.377 & 0.106 & 0.231 & 1.338 & 0.703 & 0.042 & 0.336 & 0.116 & 0.49 \\
\hline 2009 & 0.356 & 0.104 & 0.228 & 1.348 & 0.697 & 0.042 & 0.327 & 0.112 & 0.492 \\
\hline 2010 & 0.401 & 0.101 & 0.206 & 1.380 & 0.629 & 0.041 & 0.318 & 0.106 & 0.488 \\
\hline 2011 & 0.415 & 0.102 & 0.204 & 1.321 & 0.638 & 0.041 & 0.310 & 0.103 & 0.49 \\
\hline 2012 & 0.416 & 0.101 & 0.197 & 1.271 & 0.617 & 0.041 & 0.303 & 0.094 & 0.487 \\
\hline 2013 & 0.387 & 0.098 & 0.180 & 1.313 & 0.608 & 0.040 & 0.297 & 0.089 & 0.499 \\
\hline 2014 & 0.366 & 0.094 & 0.174 & 1.304 & 0.573 & 0.040 & 0.292 & 0.084 & 0.493 \\
\hline 2015 & 0.360 & 0.095 & 0.185 & 1.326 & 0.573 & 0.039 & 0.284 & 0.080 & 0.491 \\
\hline
\end{tabular}

2) Trend of disparity in fiscal decentralization indicators

Regional disparities in the amount of fiscal decentralization of metropolitan and provincial areas of Korea show a tendency to decrease. In the case of the disparity of financial independence ratio have been found to be stable since 2013. On the other hand, the disparity of fiscal self-reliance ratio, percentage of local governments' own program expenditure, and ratio of local government labor cost show gradually decreased. 
[Table 4] Trend of the Disparity of Fiscal Decentralization (2000-2015)

\begin{tabular}{c|r|r|r|r}
\hline Year & $\begin{array}{c}\text { Financial } \\
\text { Independence } \\
\text { ratio }\end{array}$ & $\begin{array}{c}\text { Fiscal } \\
\text { Self-reliance } \\
\text { Ratio }\end{array}$ & $\begin{array}{c}\text { Percentage of } \\
\text { Local Governments' } \\
\text { Own Program } \\
\text { Expenditure }\end{array}$ & $\begin{array}{c}\text { Ratio of } \\
\text { Local Governments' } \\
\text { Labor Cost }\end{array}$ \\
\hline 2000 & 0.049 & 0.500 & 0.189 & 0.352 \\
\hline 2001 & 0.080 & 0.454 & 0.247 & 0.470 \\
\hline 2002 & 0.073 & 0.460 & 0.199 & 0.440 \\
\hline 2003 & 0.070 & 0.472 & 0.237 & 0.478 \\
\hline 2004 & 0.067 & 0.468 & 0.312 & 0.467 \\
\hline 2005 & 0.084 & 0.460 & 0.170 & 0.480 \\
\hline 2006 & 0.088 & 0.459 & 0.172 & 0.454 \\
\hline 2007 & 0.096 & 0.451 & 0.165 & 0.447 \\
\hline 2008 & 0.084 & 0.442 & 0.209 & 0.472 \\
\hline 2009 & 0.088 & 0.460 & 0.199 & 0.465 \\
\hline 2010 & 0.086 & 0.426 & 0.197 & 0.464 \\
\hline 2011 & 0.092 & 0.443 & 0.190 & 0.443 \\
\hline 2012 & 0.083 & 0.434 & 0.195 & 0.429 \\
\hline 2013 & 0.075 & 0.425 & 0.183 & 0.421 \\
\hline 2014 & 0.065 & 0.397 & 0.164 & 0.448 \\
\hline 2015 & 0.069 & 0.386 & 0.168 & 0.441 \\
\hline
\end{tabular}

3) Correlation between fiscal decentralization and regional disparity

To examine the relationship between the disparity of the amount of fiscal decentralization and regional disparity, this paper sets four indicators related to fiscal decentralization as independent variables and sets each indicator of regional disparity as a dependent variable. This paper derives an inherent correlation between indicators concerning fiscal decentralization and degree of regional disparity using multiple regression analysis. 
[Table 5] Correlation between Fiscal Decentralization and Regional Disparity

\begin{tabular}{c|c|c|c|c}
\hline & $\begin{array}{c}\text { Financial } \\
\text { independence } \\
\text { ratio }\end{array}$ & $\begin{array}{c}\text { Fiscal } \\
\text { self-reliance } \\
\text { ratio }\end{array}$ & $\begin{array}{c}\text { Percentage of } \\
\text { local } \\
\text { governments' } \\
\text { own program } \\
\text { expenditure }\end{array}$ & $\begin{array}{c}\text { Ratio of local } \\
\text { governments' } \\
\text { labor cost }\end{array}$ \\
\hline $\begin{array}{c}\text { GRDP per Capita } \\
\text { Private consumption Expenditure } \\
\text { per capita }\end{array}$ & $0.647 *$ & -0.143 & -0.007 & 0.147 \\
\hline $\begin{array}{c}\text { Percentage of employees with } \\
\text { college graduated }\end{array}$ & -0.584 & $1.009 * * *$ & -0.046 & 0.284 \\
\hline $\begin{array}{c}\text { Percentage of research and } \\
\text { development costs per GRDP }\end{array}$ & $-4.770 * *$ & $1.937 * *$ & -0.320 & 0.882 \\
\hline $\begin{array}{c}\text { Industrial Property right granted } \\
\text { Percentage of population ages } 15-\end{array}$ & -0.907 & $2.962 * * *$ & $-0.645 *$ & $1.249 * *$ \\
\hline 64 & $0.216 * *$ & $-0.070 * *$ & 0.002 & -0.008 \\
\hline $\begin{array}{c}\text { Ageing Index } \\
\text { Percentage of employees with }\end{array}$ & $-0.863 *$ & $1.108 * * *$ & -0.063 & $0.446 * *$ \\
\hline $\begin{array}{c}\text { Ratio of employment in } \\
\text { manufacturing }\end{array}$ & -0.329 & $0.674 * * *$ & -0.028 & 0.179 \\
\hline$* * * p<0.01 ; * * p<0.05 ; * \mathrm{p}<0.1$ & $1.031 *$ & $-0.591 * *$ & 0.018 & -0.342 \\
\hline
\end{tabular}

As a result of the analysis it is shown that the disparity in fiscal decentralization ratio has a positive correlation with GRDP per capita, private consumption expenditure per capita, percentage of population ages 15-64 and ratio of employment in manufacturing and these was statistically significant. On the other hand, the disparity of percentage of research and development cost per GRDP ageing index and ratio has a negative correlation.

The disparity in fiscal self-reliance ration has a statistically significant correlation with almost dependent variables excluding private consumption expenditure per capita. According to the result, fiscal self-reliance ration has a negative correlation with GRDP per capita, percentage of population ages 15-64 and ratio of employment in manufacturing. On the other hand, the disparity of fiscal decentralization indicators that related to local governments' expenditure, there have statistically significant correlate with regional disparity variables in a relatively small part.

In the case of the disparity of percentage of local governments' own program expenditure has a statistically significant correlation with the disparity of GRDP per capita and the disparity of industrial property right granted. In addition, ratio of local governments' labor cost has a significant correlation with the disparity of GRDP per capita, the disparity of 
industrial property right granted and the disparity of ageing index.

As a result of analysis the correlation between the disparity of fiscal decentralization indicators and regional disparity, fiscal decentralization does not have a positive correlation to regional disparities in the same way. Moreover, it was found that progress in fiscal decentralization deepens regional disparity in some indicators.

\section{Conclusion}

This paper examined correlations between fiscal decentralization and regional disparity for 16 metropolitan and provincial areas of Korea. Financial independence ratio and fiscal selfreliance ratio indicators, those are relate to local governments' revenue decentralization have a statistically significant correlation with regional disparity. However, percentage of local government's own program expenditure and ratio of local governments' labor cost indicators, those are relate to fiscal expenditure have relatively less impact on regional disparity. According to the result of this study's analysis, local governments' revenue and expenditure decentralization have a different impact on regional disparity each other.

Decentralization of fiscal revenue allows residents to recognize that public services are offered through local taxes they incur and will closely monitor bureaucrats of local governments. Naturally, local governments are making efforts to provide services that match the preferences of residents in order to expand their finances. Moreover, local governments will make efforts to improve productivity and reduce costs through technological innovation and experiments.

In the case of South Korea, decentralization of expenditure is based on the securing of general financial resources including local allocation tax. However, decentralization of expenditure can cause moral hazard and inefficiency by inducing strategic and opportunistic behavior of local governments with soft budget constraint by local allocation tax.

There is a limit to conclude that the progress of decentralization has a positive influence on easing the regional disparities. In other words, promotion of fiscal decentralization under the circumstances where the central government's adequate financial and policy support has not been implemented can result in deepening the regional disparity.

For these reasons, in order to achieve balanced regional development and easing the regional disparity, it is necessary not only to improve the financial capacity of each local government and progress fiscal decentralization, but also consider the policy that includes central governments' fiscal adjustment intervention to be parallel.

\section{References}

Bartels, L. M. (2005). Economic Inequality and Political Representation, Annual meeting of the American Political Science Association, Boston Marriott Copley Place, Sheraton Boston \& Hynes Convention Center, Boston, Massachusetts Online.

Boadway, R. (2004). How well is the equalization system reducing fiscal disparities?. Government of Prince Edward Island.

Brennan G, Buchanan J (1980). The power to tax. Analytical foundations of a fiscal constitution. Cambridge: Cambridge University Press, 
Breton, A. (1996). Competitive governments. An economic theory of politics and public finance. New York: Cambridge University Press.

Jorge Martinez-Vazquez, and Rider, M. (2006). Fiscal decentralization and economic growth: A comparative study of China and India. Indian Journal of Economics \& Business, Special Issue China \& India, 1-18.

McKinnon, R. (1997). Market-preserving fiscal federalism in the American monetary union. In: Blejer M, Ter-Minassian T (eds) Macroeconomic dimensions of public finance: Essays in honour of Vito Tanzi. London: Routledge,

Shahateet, M. (2006). How Serious Regional Economic Inequality in Jordan?: Evidence from Two National Household Surveys. American Journal of Applied Sciences, 3(2), 17351744.

Qian, Y., Weingast, B. (1997). Federalism as a commitment to preserving market incentives. Journal of Economic Perspectives, 11, 83-92.

Salmon, P. (1987). Decentralization as an incentive scheme. Oxford Review of Economic Policy, 3(2), 24-43.

Weingast, B. (1995). The economic role of political institutions: Market-preserving federalism and economic development Journal of Law, Economics, and Organization, $11,1-31$.

Yilmaz, Y., Hoo, S., Nagowski, M., Rueben, Kim., S. and Tannenwald, R. (2006). Measuring fiscal disparities across the U.S. States: A representative revenue system/representative expenditure system approach, fiscal year 2002, FRB of Boston public policy discussion paper. Retrieved from SSRN: https://ssrn.com/abstract=1957339 or http://dx.doi.org/10.2139/ssrn.1957339

Zhao, Z. (2008). Fiscal decentralization and provincial-level fiscal disparities: Decomposing the inequality measures. Association for budgeting and Financial Management $20^{\text {th }}$ AnnualConference.

Zhao, Z. and Hou, Y. (2008). Local option sales taxes and fiscal disparity: The case of Georgia counties. Public Budgeting \& Finance, Spring. 